\title{
DEMOKRASI SEBAGAI POLA HIDUP MENURUT JOHN DEWEY
}

\author{
CB. Mulyatno*
}

\begin{abstract}
John Dewey expresses repeatedly that the significance of democracy is more than political discourse. He invites us to realize that democracy is primarily a moral idea that animates the process of living and should be actualized continuously. He stresses that the idea of liberty, equality and fraternity, which is the democratic trinity, is an ethical ideal of humanity in which the person is at the centre of reflection. Every human individual is free to actualize his or her self-realization. Liberty is based on the belief that every human individual has a right to equal opportunity with every other person to develop whatever endowment he or she has. Democracy includes fraternity as an ethical value by which every human individual is able to actualize his or her capacities only in an actively cooperative relationship with others. Political and social democracy in a real life context will be effectively sustained if its values of ideal humanity become an animating force of life. In other words, Dewey envisions democracy as a personal way of life.
\end{abstract}

Keywords: Values of democracy, social responsibility, culture of democracy, transformation of life, peaceful life.

\begin{abstract}
Absrak: John Dewey menyatakan berulangkali bahwa demokrasi lebih dari sekedar persoalan politik. Ia menunjukkan bahwa demokrasi pertama-tama merupakan sebuah gagasan etis yang menjiwai proses hidup secara terus-menerus. Kebebasan, kesederajatan, dan persaudaraan yang menjadi inti demokrasi merupakan nilai-nilai etis kemanusiaan yang menjadi arah hidup manusia di dalam kehidupan bersama di tengah masyarakat. Setiap individu adalah bebas untuk mewujudkan dirinya. Kebebasannya didasarkan pada keyakinan bahwa setiap individu mempunyai hak dan kesempatan yang sama untuk mengembangkan diri sesuai dengan potensi yang dianugerahkan kepa-
\end{abstract}

* CB. Mulyatno, Program Studi Ilmu Teologi, Fakultas Teologi, Universitas Sanata Dharma, Jl. Kaliurang KM 7, Jogjakarta 55011.E-mail: carlomul@gmail.com. 
danya. Persaudaraan merupakan nilai etis yang menegaskan bahwa setiap individu hanya mampu mewujudkan diri di dalam relasi dan kerja sama dengan sesamanya. Ketiga nilai etis tersebut seharusnya menjiwai tata hidup bersama. Dengan kata lain, demokrasi seharusnya menjadi pola hidup setiap pribadi sebagai anggota masyarakat.

Kata-kata Kunci: Nilai-nilai demokrasi, tanggung jawab sosial, budaya demokrasi, transformasi hidup, hidup damai.

\section{PENDAHULUAN}

Demokrasi merupakan istilah sosial politik yang digunakan sejak sebelum tarikh Masehi. Istilah ini muncul dalam sejarah pemerintahan di Athena sejak abad V sebelum Masehi. Athena dikelola secara demokratis karena setiap anggota masyarakat berpartisipasi secara aktif dalam penentuan kebijakan kehidupan bersama. Setiap anggota masyarakat memiliki hak dan kesempatan untuk terlibat secara langsung dalam diskusi dan penentuan kebijakan masyarakat.

Di zaman sekarang ini, demokrasi cenderung dipahami secara sempit sebagai bentuk atau mekanisme pemerintahan suatu negara yang menjunjung tinggi kedaulatan rakyat (pemerintahan dari rakyat, oleh rakyat, dan untuk rakyat). Mengingat jumlah anggota masyarakat sedemi-kian banyak dan wilayah suatu negara juga sangat luas, maka keterlibatan setiap anggota masyarakat tidak dapat dilaksanakan secara langsung. Keterlibatan itu diwakili oleh para wakil rakyat di dalam parlemen yang telah dipilih oleh rakyat.

Ada kecenderungan bahwa demokrasi sering kali hanya dimengerti sebagai sebuah bentuk pemerintahan. Keberhasilan demokrasi hanya diukur dengan pengelolaan pemerintahan berdasarkan tiga pilar atau prinsip trias politica yang membagi kekuasaan politik negara ke dalam kekuasaan eksekutif, yudikatif, dan legislatif. Ketiga kekuasaan itu mempunyai kedudukan sejajar. Kesejajaran ketiga lembaga negara ini diperlukan agar ketiga lembaga negara ini dapat saling mengawasi dan saling mengontrol. Pemilihan Umum menjadi salah satu sarana penting untuk mengak- 
tualisasikan demokrasi. Demokrasi cenderung menjadi ideologi yang mengabsahkan praktik mengorbankan kepentingan kelompok kecil (minoritas-kalah) demi kepentingan kelompok lebih besar (mayoritaspemenang) tanpa mempertimbangkan argumentasi apa pun yang menyertai keputusan tersebut.

Amerika Serikat dikenal sebagai negara yang mempelopori perkembangan demokrasi. Namun demikian, praksis kehidupan di Amerika tidak selalu mencerminkan nilai-nilai demokrasi. Hal ini menggelisahkan hati nurani John Dewey dan mendorongnya untuk memberikan sum-bangan nyata agar demokrasi menjiwai praksis hidup bermasyarakat. Dengan kata lain, ia memperjuangkan agar demokrasi sungguh menjadi pola hidup.

Tulisan ini menguraikan tiga hal pokok. Pertama adalah fenomena ancaman terhadap nilai-nilai demokrasi. Kedua adalah gagasan Dewey mengenai etika demokrasi. Ketiga adalah budaya demokrasi. Pada akhir dari tulisan ini akan disajikan sebuah penutup yang menggarisbawahi beberapa gagasan Dewey tentang pembangunan budaya demokrasi agar demokrasi menjadi pola hidup.

\section{ANCAMAN TERHADAP NILAI-NILAI DEMOKRASI \\ Perang dan Kekerasan}

Situasi perang dan kekerasan mewarnai perjalanan hidup Dewey. Sejak usia dua tahun, ia telah hidup dalam suasana kekerasan dan perang di Amerika Serikat yang dipicu oleh persoalan perbudakan terhadap para imigran, terutama para warga kulit hitam. Ancaman perpecahan antarwilayah sangat nyata, terutama di Amerika Utara. ${ }^{1}$ Ia harus berpisah dari ayahnya yang menjadi relawan perang dari tahun 1861 sampai dengan tahun 1865. Dalam skala luas, perang terjadi selama masa hidup Dewey, di antaranya adalah perang Jepang-Rusia (1904-1905), Perang Dunia I (19141918), dan Perang Dunia II (1939-1945). Dewey melihat bahwa perang dan kekerasan mengakibatkan kehancuran dan meninggalkan luka bagi manusia. Perang dan kekerasan merupakan kekalahan kemanusiaan karena telah

1 George Brown Tindall and David Emory Shi, America: A Narrative History (New York: Norton \& Company, 2000), p. 470. 
menciptakan tembok pemisah yang meluluhlantakkan kesederajatan dan persahabatan yang menjadi pilar perdamaian. Perdamaian dan keadilan tidak mungkin dicapai melalui perang dan kekerasan.

John Dewey merupakan saksi berkembangnya gerakan totalitarianisme dan otoritarianisme. Fasisme Italia di bawah kepemimpinan Benito Mussolini, Nazisme Jerman di bawah pimpinan Adolf Hitler, Komunisme Soviet di bawah Stalin dan kemudian berkembang di China merupakan sederet ideologi bercorak totalitarian. ${ }^{2}$ Berbagai peristiwa perang dan gerakan totalitarian yang jelas-jelas anti demokrasi itu meninggalkan kegelisahan mendalam dalam hati Dewey. ${ }^{3}$ Ia melihat bahwa demokrasi yang selama bertahun-tahun diperjuangkan di Amerika Serikat dan berbagai tempat berhadapan dengan ancaman yang nyata.

Perang dan gerakan totalitarian telah mencabik budaya kebebasan. Ancaman paling membahayakan hidup manusia bukan hanya disebab-kan oleh peluru dan senapan melainkan oleh cara pandang terhadap kehidupan dan ideologi yang menebar teror terhadap kemerdekaan dan kebebasan hidup manusia. ${ }^{4}$ Sentimen terhadap ras dan perlakuan tidak adil terhadap warga kulit hitam dan umat Katolik serta Yahudi merupakan bentuk ancaman terhadap martabat umat manusia yang berasal dari dalam diri manusia sendiri. Bagi Dewey, perlakuan tidak adil (diskri-minatif) terhadap warga kulit hitam (negro) dan umat Katolik serta Yahudi identik atau tidak jauh berbeda dengan tindakan tidak manusiawi (biadab) rezim Nazi Jerman terhadap warga keturunan Yahudi. ${ }^{5}$ Apa pun argu-mentasinya, sikap diskriminatif dan tindakan kekerasan terhadap kelompok masyarakat tertentu merupakan bentuk sikap dan tindakan anti demokrasi.

Secara khusus Dewey menentang rasisme atau sikap dan tindakan

2 Bdk. Mario Einaudi, "Fascism," in International Encyclopedia of the Social Science, Volume V, edited by David L. Sills (New York: The MacMillan Company \& The Free Press, 1968), p. 335.

3 Robert B. Westbrook, John Dewey and American Democracy (Ithaca: Cornel University Press, 1991), p. 2.

4 John Dewey, "Democratic Ends Need Democratic Methods for Their Realization," in The Political Writings, edited by Debra Morris and Ian Shapiro (Indianapolis: Hackett Publishing Company, 1993), p. 205.

5 John Dewey, Freedom and Culture (New York: Prometheus Books, 1989), p. 99. 
diskriminatif terhadap warga kulit hitam. Baginya, segala bentuk rasisme dan diskriminasi merupakan rongrongan terhadap demokrasi. ${ }^{6}$ Sebagai tindakan nyata untuk memperjuangkan nilai-nilai demokrasi, yaitu keadilan dan kesederajatan, ia terlibat dalam mendirikan National Association for the Advancement of Coloured People (NAACP), sebuah organisasi yang memperjuangkan penegakan hak-hak masyarakat sipil terutama untuk membela hak-hak warga kulit hitam. ${ }^{7}$ Organisasi ini didirikan pada Januari 1909 di Amerika Utara. Melalui organisasi ini, ia terlibat dalam membangun gerakan masyarakat sipil untuk menumbuhkan kesadaran bersama akan pentingnya memperjuangkan keadilan dan kesamaan hak bagi semua warga masyarakat.

Sebagai penggulat ilmu filsafat, Dewey berusaha menemukan sumbangan filsafat bagi pengembangan budaya yang menjunjung tinggi perdamaian dan mengatasi berbagai persoalan kemanusiaan. ${ }^{8}$ Dewey menemukan hubungan erat antara filsafat, pendidikan, dan pengembangan budaya damai. Untuk menjelaskan hubungan filsafat dan pen-didikan, ia menemukan inspirasi dari model berfilsafat Sokrates yang menjunjung tinggi dialog sebagai bentuk pendidikan masyarakat, khusus-nya generasi muda. Sokrates telah menjadikan filsafat membumi dan mengembangkan metode dialog sebagai cara untuk mendidik masyarakat. ${ }^{9}$ Dewey menemukan titik temu antara filsafat, pendidikan, dan pengembangan demokrasi. Baik filsafat maupun pendidikan secara hakiki merupakan proses pencerahan dan pengembangan karakter masyarakat, khususnya generasi muda; filsafat dan pendidikan berarti proses transformasi budaya demokrasi. ${ }^{10}$ Filsafat dan pendidikan merupakan proses mengembangkan karakter pribadi manusia yang ditandai oleh tanggung jawab sosial untuk mengembangkan nilai-nilai keadilan dan perdamai-

6 John Dewey, “Democratic Ends....," p. 205.

7 Garry Bullert, The Politics of John Dewey (New York: Buffalo Press, 1983), p. 35.

8 Garry Bullert, The Politics of John Dewey, p. 9.

9 "Socrates brought philosophy down from the heavens to earth. It is often forgotten that this change coincided with interest in education; it was an outgrowth of interest in the possibilities of education in its large sense." John Dewey, "Philosophy and Education," in The Later Works $V$, edited by Jo Ann Boydston (Carbondale: Southern Illinois University Press, 1978), p. 289. 
an. Bagi Dewey, berkembangnya tanggung jawab sosial untuk mengembangkan keadilan dan perdamaian dalam diri warga masyarakat merupakan tanda jelas berkembangnya budaya demokrasi; maka, filsafat semestinya membantu untuk mentransformasikan pendidikan agar keduanya membantu pengembangan hidup bersama yang demokratis. Tragedi kemanusiaan di Jerman pada zaman Hitler menjadi cermin bahwa pendidikan telah kehilangan hakikatnya sebagai sarana pencer-dasan dan pengembangan budaya. Pemerintahan Hitler telah meman-faatkan pendidikan sebagai alat efektif untuk menanamkan ideologi politik yang menghalalkan kekerasan demi mempertahankan kekua-saan. ${ }^{11}$

Dewey menyadari bahwa pendidikan mengemban tiga tugas penting, yaitu menyuarakan kebenaran, mencari jalan untuk memecahkan persoalan kemanusiaan, dan memperjuangkan agar nilai-nilai demokrasi dihayati oleh setiap warga masyarakat. Tugas penting para filosof dan pendidik adalah memperjuangkan reformasi pendidikan dan transformasi kehidupan berpolitik. ${ }^{12}$ Dalam rangka menyuarakan pentingnya transformasi pendidikan, Dewey mengunjungi Jepang dan China untuk memberikan kuliah di berbagai Universitas. Dewey yakin bahwa berbagai persoalan sosial-kemanusiaan terkait dengan persoalan bagaimana menjadikan pendidikan sebagai proses mengembangkan dan mewujudkan kecerdasan sosial. Masyarakat terdidik semestinya memiliki kepeka-an dan tanggung jawab untuk memperjuangkan keadilan dan perda-maian dalam hidup bersama. ${ }^{13}$ Baginya, pendidikan seharusnya berpu-sat pada pengalaman dan menjadi proses rekonstruksi pengalaman (reconstruction of experience) secara kontinyu, sehingga menghasilkan pribadi-pribadi yang cerdas dan cinta damai. ${ }^{14}$ Mengembangkan filsafat yang mencerdaskan dan membumi, pendidikan yang bervisi sosial dan transformasi budaya merupakan pilihan Dewey untuk memberikan sumbangan nyata guna

10 "Education - in the broad sense of formation of fundamental attitudes of imagination, desire and thinking - is strictly correlative with culture in its inclusive social sense." John Dewey, Individualism: Old and New (New York: Prometheus Books, 1999), p. 63.

11 John Dewey, Freedom and Culture (New York: G.P. Putnam's Sons, 1989), p. 99.

12 Garry Bullert, The Politics of John Dewey, p. 91.

13 John Dewey, Liberalism and Social Action (New York: G.P. Putnam's Sons, 2000), p. 82. 
mengembangkan demokasi.

\section{MASYARAKAT INDUSTRI}

Dewey hidup di tengah perkembangan industri yang ditopang oleh kemajuan ilmu dan teknologi modern. Munculnya kota-kota industri diiringi dengan urbanisasi besar-besaran. Dewey melihat kehidupan urban yang warganya sebagian besar adalah pekerja pabrik. Satu-satunya sumber penghasilan adalah upah kerja. Perhatian mereka terfokus pada usaha untuk memenuhi kebutuhan ekonomi keluarga. Mereka berangkat pagipagi dan pulang petang untuk bekerja sehingga tidak mempunyai waktu cukup untuk berinteraksi dengan tetangga. Akibatnya, mereka tidak saling mengenal sehingga kepedulian, soli-daritas, dan kerja sama antarwarga yang sangat kental di masyarakat pertanian menjadi langka di dalam masyarakat industri. ${ }^{15}$ Iklim hidup bersaudara dan saling menghormati yang merupakan kualitas hidup damai semakin jauh dari kehidupan masyarakat industri. Masyarakat didominasi oleh suasana kompetisi atau persaingan.

Kompetisi juga merambah dunia pendidikan. Demi kepentingan penyiapan tenaga kerja, banyak lembaga pendidikan berlomba-lomba menyelenggarakan pelatihan tenaga kerja. Orientasi pada penyediaan tenaga kerja membuat lembaga pendidikan mengabaikan pengem-bangan karakter dan pendidikan nilai. Akibatnya, anak-anak dan generasi muda dengan mudah menjadi alat kepentingan orang tua dan kepentingan industri. Secara khusus, anak-anak menjadi warga masya-rakat yang dengan mudah menjadi alat pengembangan pasar industri. Banyak barang konsumsi diproduksi dan dipasarkan di kalangan anak-anak, namun tidak banyak barang yang memang diperlukan untuk pengembangan diri dan pendidikan anak.

Produksi barang dalam jumlah besar dengan pertimbangan efisiensi telah mewarnai perkembangan industri. ${ }^{16}$ Industri pers berkembang subur demi kepentingan penawaran barang kepada masyarakat, terutama anak-

14 John Dewey, Experience and Education, p. 47.

15 John Dewey, Freedom and Culture, p. 118. 
anak. Media massa tidak hanya menjadi ujung tombak untuk menawarkan barang melainkan juga membangun imajinasi bahwa barang-barang yang ditawarkan seolah-olah merupakan kebutuhan yang mencitrakan harga diri si pengguna. Masyarakat industri secara kasat mata tidak berpihak kepada pendidikan anak-anak. Anak-anak tidak mendapatkan iklim kehidupan yang memungkinkan mereka untuk mengeksplorasi diri secara kreatif karena sejak kecil sudah dibiasakan dan dijadikan mangsa pasar industri yang menciptakan sikap konsumtif.

Dari sisi pemilik modal, warga masyarakat, terutama anak-anak, dilihat sebagai peluang untuk melipatgandakan keuntungan material. Sementara dari sisi konsumen (terutama anak-anak), iklim kehidupan yang cenderung konsumtif mendorong pilihan-pilihan bukan berdasar-kan nilai-nilai yang luhur melainkan berdasarkan pemenuhan dan pemuasan diri dengan cara memiliki dan mengkonsumsi barang-barang dengan cara mudah. Nilai kegunaan dan kepuasan telah mendominasi pertimbangan, sehingga nilai-nilai estetis (seni), sosial, dan religius mulai tergerus. ${ }^{17} \mathrm{Pada}$ gilirannya, uang merupakan kekuatan yang sangat berkuasa mengatur hidup. Dewey melihat dominasi budaya uang meng-geser faktor spiritual dan tradisi, penghargaan terhadap kesamaan kesempatan, semangat bekerja sama dan komunikasi secara bebas. ${ }^{18}$ Perkembangan industri yang mengusung budaya uang membawa akibat sangat mendalam, yaitu terkikisnya pilar-pilar demokrasi dan peradaban umat manusia, maka Dewey meyakini bahwa mengembangkan demokrasi sejalan dengan perjuangan membangun budaya yang menjunjung tinggi semangat dialog dan nilai-nilai manusiawi (kebenaran, keadilan, persau-daraan, dan tanggung jawab sosial) demi terwujudnya kehidupan ber-sama yang semakin damai. ${ }^{19}$

Sebagai bentuk nyata kepeduliannya terhadap persoalan kema-

16 John Dewey, Freedom and Culture, p. 118.

17 Bdk. Friedrich Schiller, On the Aesthetic Education of Man (Mineola, NY: Dover Publications, Inc., 2004), p. 3.

18 "If it is incapable of developing moral techniques which will also determine their relations, the split in modern culture goes so deep that not only democracy but all civilized values are doomed." John Dewey, Individualism: Old and New, p. 9. 
nusiaan yang diakibatkan oleh perkembangan industri, sejak 1916 Dewey terlibat secara aktif dalam Perkumpulan Kaum Buruh di Amerika Serikat. Ia memfokuskan perhatiannya pada usaha mereformasi pendidikan. ${ }^{20}$ Pada 1933 ia mengalami saat-saat prihatin bersama dengan sekitar tiga belas juta orang yang terkena pemutusan hubungan kerja dan pengu-rangan jam kerja akibat krisis ekonomi di Amerika Serikat yang ber-dampak buruk bagi pengelolaan industri. ${ }^{21}$ Baginya, persoalan buruh di era industri merupakan persoalan kemanusiaan yang harus dihadapi dan dicarikan jalan keluar dengan pertimbangan yang luas dan mendalam didasarkan pada nilai-nilai demokrasi. Ia menegaskan "If there is to be genuine and adequate democracy there must be a radical transformation of the present controls of production and distribution of goods and services, ${ }^{22}$ maka, demokrasi semestinya mencerahi dan menyemangati manusia untuk peduli terhadap upaya mengatasi berbagai persoalan sosial dan membangun hidup bersama yang bermartabat. ${ }^{23}$ Untuk itu, Dewey melihat pentingnya mengembangkan pendidikan karakter pribadi sejak anak-anak berusia dini.

Dewey meyakini bahwa proses pendidikan karakter harus dimulai sejak anak-anak usia Sekolah Dasar. Berdasarkan pertimbangan itu, pada 1894 Dewey bekerja sama dengan banyak pihak untuk mengem-bangkan laboratorium Sekolah Dasar. ${ }^{24}$ Ia menggandeng William Rainey Harper (pemerhati pendidikan di Amerika Serikat), James R. Angell dan George Herbert Mead (dosen di Universitas Michigan), James H. Tufts (peneliti di bidang etika), serta Scribner Ames dan Addison W. Moore (lulusan Universitas Chicago yang sangat peduli terhadap persoalan pendidikan) untuk mengembangkan laboratorium Sekolah Dasar. Bagi Dewey, pendidikan merupakan tempat menghidupi nilai-nilai, yaitu penghargaan

19 CB. Mulyatno, "Philosophy as An Educative Prosess in John Dewey (sic) Pragmatism," Studia Philosophica et Theologica 9 (2009): 80-81.

20 Amalia De Maria, Invito al pensiero di John Dewey (Milano: Mursia, 1990), p. 28.

21 George Brown Tindall and David Emory Shi, America: A Narrative History, p. 939.

22 John Dewey, Freedom and Culture, p. 64.

23 John Dewey, "Creative Democracy - The Task Before Us," in The Political Writings, edited by Debra Morris and Ian Shapiro (Indianapolis: Hackett Publishing Company, 1993), p. 244. 
terhadap perbedaan, keadilan, kesederajatan, perdamaian, dan tanggung jawab sosial di dalam diri warga masyarakat sejak anak-anak.

\section{Reduksi Demokrasi}

Demokrasi telah menjadi kebanggaan masyarakat dan pemerintah Amerika Serikat. Kehidupan berpolitik merupakan ajang untuk mempraktikkan demokrasi, namun ketika demokrasi lebih banyak digu-nakan sebagai jargon politik dan kurang dimaknai secara etis, Dewey melihat bahaya nyata adanya pendangkalan makna demokrasi. Kenya-taannya demokrasi memang sering direduksi ke ranah politik dan dijadi-kan alat pembela kekuasaan serta kepentingan ekonomi bagi mereka yang sedang berkuasa. ${ }^{25}$ Bagaimana hal itu terjadi? Dengan otoritas dan kekayaan yang dimilikinya, para pemegang kekuasaan dapat menguasai akses media dan pendidikan untuk mempropagandakan ideologi yang berpihak kepada kepentingan mereka, meskipun mereka seolah-olah berpihak pada dan memperjuangkan kepentingan rakyat. Istilah demi kepentingan rakyat dapat mengelabui banyak orang karena rakyat cenderung menjadi objek yang diharapkan menjadi pendukung mayoritas, sehingga pemerintah dapat mempertahankan kekuasaannya.

Mereduksi demokrasi ke bentuk pemerintahan merupakan kesalahan serius yang harus dibenahi. ${ }^{26}$ Memang penataan kehidupan bersama atau kehidupan berpolitik secara demokratis amat penting, akan tetapi harus disadari bahwa demokrasi pertama-tama merupakan cara dan nilai-nilai kemanusiaan yang mendasari hidup bersama. ${ }^{27}$ Pada tahun 1890-an, ketika banyak gerakan reformasi politik yang menekan-kan upaya peningkatan partisipasi warga dalam kehidupan berpolitik, Dewey justru memfokuskan perhatiannya pada pengembangan hidup bersama yang beretika demokrasi; artinya, hidup bersama yang adil dan damai tidak mungkin tercapai jika demokrasi hanya dipahami sebagai sebuah sistem politik. Demokrasi harus menjadi dasar etis (sikap dan perilaku) setiap 24 Jane M. Dewey, "Biography of John Dewey," in The Philosophy of John Dewey, Volume I, edited by Paul Arthur Schilpp (New York: The Library of Living Philosophers, 1951), p. 77.

25 John Dewey, The Public and Its Problems (Ohio: Ohio University Press, 1997), pp. 93-95.

26 John Dewey, “Creative Democracy ....," p 241. 
warga masyarakat dalam relasi dengan sesamanya.

John Dewey melihat gejala pemahaman demokrasi yang diper-sempit menjadi kebebasan individu dalam bidang pengembangan ekonomi yang memposisikan peran utama pemerintah pada pengem-bangan kesejahteraan ekonomi setiap warga negara. ${ }^{28}$ Meskipun ia membela kepentingan dan melindungi hak setiap individu untuk hidup sejahtera di tengah masyarakat, ia tidak setuju dengan pemaknaan demokrasi hanya dilihat dari peran dan fungsinya untuk menye-jahterakan individu-individu. Ia menentang pemikiran James Will yang menekankan pentingnya pemerintahan yang demokratis hanya sebagai sarana untuk melindungi dan mengembangkan kesejahteraan ekonomi individu-individu. ${ }^{29}$ Perkembangan setiap individu tidak hanya diukur dari tingkat kesejahteraan ekonomis belaka. Baginya, setiap pribadi hanya dapat berkembang dalam relasi timbal balik dengan sesama dan interaksi di tengah kehidupan masyarakat. Pemerintahan yang demo-kratis hanya dapat dibangun dan dikembangkan jika setiap individu saling menghargai hak dan kebebasan sesamanya. Dengan kata lain, pemerintahan yang demokratis hanya akan berkembang kalau setiap individu sungguh memahami dan menghayati nilai-nilai demokratis dalam kehidupan sehari-hari.

Pemikiran John Dewey sejalan dengan Thomas Jefferson, salah seorang founding fathers demokrasi di Amerika Serikat yang menegaskan bahwa demokrasi merupakan konsep moral yang berhubungan dengan etika hidup manusia; ${ }^{30}$ artinya, perjuangan untuk mengembangkan demokrasi berhubungan dengan proses membangun hidup bersama yang berkualitas dalam konteks nyata. Ketika demokrasi cenderung hanya men-jadi wacana konseptual dan ideologi politik abstrak, ia menegaskan: "We now have to re-create by deliberate and determined endeavour the kind of democracy which in its origin one hundred and fifty years ago was largely the product of a fortune combination of men and circumstances." 31

27 John Dewey, Democracy and Education (New York: The Free Press, 1916), p. 87.

28 John Dewey, "The Basic Values and Loyalty of Democracy," in The Political Writings, edited by Debra Morris and Ian Shapiro (Indianapolis: Hackett Publishing Company, 1993), p. 207.

29 Bdk. John Dewey, The Public and Its Problems, pp. 93-95. 
Sejalan dengan gagasan Thomas Jefferson, Dewey pun meyakini bahwa pemerintahan yang demokratis hanya mungkin terwujud jika ditopang oleh kebebasan pers, pendidikan yang bermutu, kehidupan warga masyarakat yang diwarnai kerja sama dan keakraban, dan kehidu-pan bersama yang diatur secara baik. ${ }^{32}$ Masyarakat demokratis adalah masyarakat yang dihuni oleh individu-individu cerdas dan mempunyai

yang tinggi. Untuk itu, ia melihat bahwa salah satu penyebab tersendatnya perkembangan demokrasi adalah rendahnya mutu pendidikan. Ia mengingatkan pengalaman kegagalan para perintis demokrasi di Amerika Serikat dalam mencermati institusi-institusi pendidikan yang telah dijadikan senjata bagi pemerintah bergaya militer yang otoriter dan menindas. ${ }^{33}$ Orientasi pada upaya melanggengkan kekuasaan dan mencapai keuntungan ekonomis membuat para pemegang kekuasaan abai terhadap tanggung jawab mencerdaskan masyarakat.

Para pemegang kekuasaan dan pemilik modal menggunakan media untuk membangun opini publik. Pers, media massa, dan berbagai publikasi yang semestinya menjadi sarana pencerdasan masyarakat sipil dan pengembangan kepedulian sosial cenderung mementingkan pemu-asan publik dengan berita-berita dan bahkan gosip sensasional yang kurang mencerdaskan. ${ }^{34}$ Terbukti bahwa gosip mengenai kehidupan pribadi para selebriti yang bernilai komersial dan mendatangkan banyak keuntungan finansial sering kali banyak menyita media daripada penayangan berita-berita yang mencerdaskan dan mengembangkan kehidupan yang demokratis. ${ }^{35}$

Demi keuntungan ekonomis, pers secara dominan mengekspos berbagai berita sensasional seperti pembunuhan, penjambretan, tawuran antarpelajar serta mahasiswa, konflik antarsuku serta agama, demons-trasi anarkis, terorisme, perselingkuhan, dan berbagai peristiwa keke-rasan lainnya. Politik uang dan teknologi menjadi pendukung kuat kepentingan

30 John Dewey, Freedom and Culture, pp. 100-101.

31 John Dewey, Freedom and Culture, p. 241.

32 John Dewey, Freedom and Culture, p. 37.

33 John Dewey, Freedom and Culture, p. 37. 
kelompok atau golongan yang mempunyai akses kekua-saan. ${ }^{36}$ Budaya akal sehat diperlemah oleh ketergantungan pada rang-sangan dari lingkungan yang ditawarkan oleh berbagai berita sensa-sional dari media. ${ }^{37}$ Istilah demokrasi sering diucapkan dan menjadi sedemikian akrab, namun isi dan maknanya menjadi kabur. Terseretnya demokrasi ke dalam wilayah politik membawa akibat terjadinya krisis budaya dan nilai-nilai kemanusiaan di tengah masyarakat. Di tengah fenomena masyarakat yang cenderung mereduksi makna demokrasi, Dewey berjuang untuk mengembalikan makna demokrasi yang otentik. Ia berjuang agar demokrasi terungkap dan terwujud dalam integritas intelektual dan moral masing-masing anggota masyarakat. ${ }^{38}$ Untuk itu, demokrasi harus menjadi bagian sikap, perilaku, dan kualitas hidup sehari-hari. ${ }^{39}$ Demokrasi akan menjadi kekuatan perubahan kalau hal itu bersentuhan dengan martabat hidup setiap individu di tengah masya-rakat. Demokrasi mempunyai makna yang jelas dan konkret ketika men-jadi kekuatan hidup sekaligus tujuan transformasi budaya yang berlang-sung terus-menerus.

\section{ETIKA DEMOKRASI}

\section{AspeK ETIS}

Aspek etis demokrasi secara jelas menyatu dengan manusia sebagai subjek dan tujuan demokrasi. ${ }^{40}$ Konsekuensinya, pembicaraan tentang demokrasi pertama-tama berhubungan dengan karakter warga masya-rakat yang mendasarkan hidup mereka pada nilai-nilai demokrasi. Kesadaran akan aspek etis ini menjadi dasar pengembangan demokrasi yang berpusat dan bermuara pada pengembangan karakter warga masyarakat dan bukan hanya pada diskusi mengenai bentuk peme-rintahan. ${ }^{41}$ Tata kelola pemerintahan harus ditempatkan sebagai sarana untuk mewujudkan nilai-nilai demokrasi yang ditandai oleh per-

34 John Dewey, Freedom and Culture, p. 40.

35 Haryatmoko, Etika Komunikasi: Manipulasi Media, Kekerasan dan Pornografi (Yogyakarta: Kanisius, 2007), hlm. 20.

36 John Dewey, Individualism: Old and New, p. 15.

37 John Dewey, Freedom and Culture, p. 38.

38 John Dewey, Freedom and Culture, p. 43.

39 John Dewey, "The Ethics of Democracy," in The Political Writings, p. 59. 
kembangan kader-kader kepemimpinan yang berkarakter demokratis. Pemerintahan dan masyarakat demokratis hanya mungkin terwujud jika setiap pribadi memahami dan menghayati nilai-nilai demokrasi.

Kebebasan (liberty), kesederajatan (equality), dan persaudaraan (fraternity) yang menjadi inti demokrasi merupakan nilai-nilai yang mendasari hidup bersama di tengah masyarakat. ${ }^{42}$ Ketiganya merupa-kan simbol gagasan etis yang menjadi dasar dan tujuan manusia. ${ }^{43}$ Nilai-nilai yang berciri spiritual (tidak kasat mata) itu menjiwai hidup masing-masing pribadi dan kehidupan bersama. Perkembangan demokrasi tidak hanya diukur dengan adanya perumusan norma dan penataan peme-rintahan dengan prinsip-prinsip demokrasi, melainkan juga dengan penghayatan nilai-nilai tersebut di atas dalam hidup masing-masing pribadi di tengah masyarakat. ${ }^{44}$

Kebebasan merupakan nilai mendasar dari demokrasi. Tentang hal ini, Dewey menegaskan:

Demokrasi adalah kebebasan. Kalau kebenaran mendasari segala sesuatu, kebebasan berarti memberi kesempatan kepada kebenaran untuk menunjukkan dirinya, kesempatan yang memancar keluar dari kedalaman. Demokrasi, sebagai kebebasan, berarti merenggangkan ikatan, melonggarkan pembatasan, mereta batas-batas, membongkar tembok pembatas dan partisi. Lewat penyingkiran pembatasan ini, kebenaran apa pun, kenyataan apa pun yang ada dalam kehidupan manusia, dibebaskan untuk mengung-kapkan dirinya. Demokrasi sebagai kebebasan, membebaskan kebenaran. Kebenaran membebaskan; tetapi membebaskan kebenaran adalah buah karya sejarah membongkar tembok isolasi dan kepentingan kelas yang terkandung di dalamnya dan di bawah permukaannya. ${ }^{45}$

40 John Dewey, "The Ethics of Democracy," p. 61.

41 Dewey menegaskan: "democracy is an ethical conception, and upon its ethical significance is based its significance as governmental. Democracy is a form of government only because it is a form of moral and spiritual association." John Dewey, "The Ethics of Democracy," p. 59.

42 John Dewey, "The Ethics of Democracy," p. 65.

43 John Dewey, "The Ethics of Democracy," p. 65.

44 Ia menegaskan: "democracy is a spiritual fact and not a mere piece of governmental machinery." John Dewey, "Christianity and Democracy," in John Dewey, The Early Works 1882-1898: Early Essays and Study of Ethics - A Syllabus 1882-1894, Volume IV (Carbondale: Southern Illinois University Press, 1971), p. 8. 
Ada dua arti penting kebebasan. Pertama, kebebasan berarti lepasnya segala ikatan. Kedua, kebebasan berarti iklim yang memung-kinkan setiap pribadi untuk mengungkapkan dan mewujudkan kebenaran. Dalam pandangan Dewey, kebenaranlah yang membuat manusia bebas. Mengingat manusia merupakan makhluk sosial, perwujudan kebebaan yang merupakan nilai penting dari demokrasi terjadi dalam proses hidup bermasyarakat yang ditandai oleh persaudaraan yang kuat. ${ }^{46}$ Dengan jelas ia menyatakan: "It is in democracy, the community of ideas and interest through community of action, that the incarnation of God in man (man, that is to say, as organ of universal truth) becomes a living, present thing, having its ordinary and natural sense." ${ }^{47}$

Dengan menekankan pentingnya aspek sosial dari demokrasi, Dewey mau menekankan bahwa kebebasan tidak boleh dimengerti hanya dalam kaitannya dengan kehidupan individual yang tidak diba-tasi oleh aturan. ${ }^{48}$ Kebebasan merupakan gagasan etis yang berhubu-ngan dengan nilai pribadi setiap manusia yang harus dilindungi di dalam kehidupan bersama. Setiap pribadi mempunyai tujuan di dalam dirinya sendiri, ${ }^{49}$ namun ia hanya dapat mewujudkan diri dan men-capai tujuannya di dalam interaksi dengan sesama dan dunia. Pemikiran Dewey tentang pribadi manusia sebagai hukum tertinggi bagi demokrasi tampaknya dipengaruhi oleh pemikiran Kant yang ia peroleh dari H.A.P. Torrey selama masa studinya. ${ }^{50}$

Dengan menegaskan bahwa kebebasan yang menjadi satu pilar penting dari demokrasi, Dewey mau menegaskan bahwa setiap pribadi yang merupakan subjek demokrasi memiliki kekuatan dari dalam dirinya untuk mewujudkan pilihan-pilihan hidupnya bersama pribadi lain. Ia menegaskan: "The democratic ideal includes liberty because democracy without

45 "Democracy is freedom. If truth is at the bottom of things, freedom means giving this truth a chance to show itself, a chance to well up from the depths. Democracy, as freedom, means loosening of bonds, the wearing away of restrictions, the breaking down of barriers, of middle walls, of partitions. Through this doing away with restriction, whatever truth, whatever reality there is in man's life is freed to express itself. Democracy is, as freedom, the freeing of truth. Truth makes free, but it has been the work of history to free truth - to break down the walls of isolation and of class interest which held it in and under." John Dewey, Christianity and Democracy, p. 8.

46 John Dewey, "Christianity and Democracy," p. 9.

47 John Dewey, “Christianity and Democracy," p. 9. 
initiation from within, without an ideal chosen from within and freely followed by initiation from within, is nothing." ${ }^{51}$

Bagaimana dengan kesamaan atau kesederajatan atau equality? Kesamaan atau kesederajatan bukan dimaksudkan sebagai kesamaan dalam hal jumlah atau pembagian yang berhubungan dengan kesejah-teraan ekonomis. Kesederajatan merupakan gagasan etis. Ia menjelaskan:

Seperti halnya kemanusiaan kesederajatan bersifat universal. Ia tidak berpihak pada semua perbedaan yang memisahkan lakilaki dari perempuan. Di mana pun terdapat seorang manusia, di sana akan ditemukan kepribadian, dan tidak terdapat jejak yang dapat membedakan seorang pribadi dari pribadi lainnya sebagai yang lebih tinggi atau lebih rendah. Hal itu berarti bahwa setiap individu memiliki kemungkinan tak terbatas dan universal... Arti yang sesungguhnya dari kesederajatan mirip dengan definisi tentang demokrasi yang diberikan oleh James Russell Lowell; yakni bentuk komunitas di mana setiap orang memiliki sebuah peluang dan ia mengetahui bahwa ia memilikinya. Kita dapat menambahkan: sebuah peluang yang tidak dapat dibatasi, peluang untuk menjadi seorang pribadi. Secara singkat, kesederajatan adalah sebuah ideal dari kemanusiaan; sebuah ideal dalam kesadaran bahwa demokrasi hidup dan bergerak..$^{52}$

Kutipan di atas menegaskan makna etis dari istilah kesederajatan atau kesamaan. Gagasan mengenai kesederajatan dalam diri manusia berdasar pada keyakinan bahwa demokrasi merupakan kondisi dan iklim hidup persaudaraan yang memungkinkan setiap pribadi mewujudkan segala potensi yang dimilikinya dalam suasana kerja sama yang dinamis. ${ }^{53}$

Sebagaimana halnya kebebasan dan kesederajatan, persaudaraan (fraternity) juga merupakan konsep etis. Dewey menjelaskan bahwa persaudaraan atau fraternity berarti " the will to work together; it is the essence of cooperation. ${ }^{\prime 54}$ Gagasan tersebut menegaskan bahwa demokrasi tidak hanya berhubungan dengan kebebasan untuk mengungkapkan pendapat dan kebebasan untuk berorganisasi melainkan juga usaha untuk membangun

48 John Dewey, "Christianity and Democracy," p. 9.

49 John Dewey, "Christianity and Democracy," p. 9.

50 Robert B. Westbrook, John Dewey and American Democracy, p. 6.

51 John Dewey, "The Ethics of Democracy," p. 62. 
kerja sama secara dinamis dalam rangka mewu-judkan keadilan dan perdamaian. Persaudaraan merupakan pilar penting demokrasi karena setiap pribadi merupakan makhluk sosial yang membutuhkan ruang lingkup yang kondusif untuk mengungkapkan tanggung jawab sosialnya. Setiap pribadi adalah unik, khas, dan hanya dapat hidup dan berkembang di dalam relasi dinamis dengan sesama dalam semangat persaudaraan. ${ }^{55}$ Dewey menggarisbawahi bahwa persaudaraan (fraternity) tidak hanya merupakan hubungan antar-individu sebagai warga masyarakat melainkan juga hubungan harmonis dengan alam sekitar. ${ }^{56}$

\section{Aspek Komuniter}

Pembicaraan mengenai demokrasi bersentuhan dengan cita-cita membangun hidup bersama. Kebebasan, kesederajatan, dan per-saudaraan yang menjadi pilar utama demokrasi semestinya menjiwai hidup masingmasing individu dalam membangun hidup bersama yang manusiawi di tengah alam semesta ini. Dengan kata lain, demokrasi merupakan tolok ukur moralitas kehidupan bersama atau hidup berko-munitas. ${ }^{57}$

Dewey menegaskan pentingnya demokrasi bagi kehidupan berkomunitas. Yang ia maksud dengan hidup berkomunitas adalah proses dinamis agar nilai-nilai demokrasi "becomes a living, present thing, having its ordinary and natural sense." ${ }^{58}$ Lebih lanjut ia menjelaskan bahwa demokrasi menjadi hidup karena demokrasi merupakan:

Sebuah kondisi kehidupan sosial di mana terdapat distribusi peluang

52 "Equality is as universal as humanity; it is indifferent to all distinction which divide men from men. Wherever you have a man, there you have personality, and there is no trace by which one personality may be distinguished from another so as to be set above or below. It means that in every individual there lives an infinite and universal possibility... The true meaning of equality is synonymous with the definition of democracy given by James Russell Lowell. It is the form of society in which every man has a chance and knows that he has it - and we may add, a chance to which no possible limits can be put, a chance which is truly infinite, the chance to become a person. Equality, in short, is the ideal of humanity; an ideal in the consciousness of which democracy lives and moves." John Dewey, The Ethics of Democracy, p. 63.

53 John Dewey, “The Basic Values...," p. 208.

54 John Dewey, “The Basic Values...," p. 209.

55 John Dewey, "Philosophy and Democracy," in The Political Writings, p. 46.

56 John Dewey, "Philosophy and Democracy," pp. 59-61. 
yang luas dan beragam; di situ terdapat mobilitas sosial atau ruang lingkup bagi perubahan kedudukan dan tempat tinggal; dalam kondisi tersebut terdapat pertukaran pengalaman dan gagasan yang bebas, yang menyebabkan terjadinya pengakuan yang luas terhadap kepentingan dan tujuan bersama, serta di mana manfaat dukungan yang langsung terasa dan terus-menerus atas nama kondisi kehidupan sosial tersebut..$^{59}$

Tentang demokrasi, Dewey menegaskan lebih lanjut: "It is moral because based on faith in the ability of human nature to achieve freedom for individuals accompanied with respect and regard for other persons and with social stability built on cohesion instead of coercion." ${ }^{60}$ Demokrasi merupakan semangat hidup bersama yang mendorong masing-masing individu untuk mengembangkan diri sekaligus bertanggung jawab terhadap perkembangan sesamanya. Demokrasi merupakan moralitas hidup bersama karena demokrasi merupakan dasar, metode, dan tujuan hidup manusia sebagai makhluk sosial. ${ }^{61}$ "The fundamental to moral democracy is a faith in the capacity of human beings for intelligent judgment and action." ${ }^{62}$ Jika demokrasi tidak menjadi semangat dan cara hidup bersama, demokrasi hanya akan menjadi jargon kosong; maka, Dewey dengan tegas menya-takan bahwa "the idea remains barren and empty save as it is incarnated in human relationship... To be realized it must affect all modes of human association, the family, the school, industry, religion." 63

Dalam buku Democracy and Education, aspek komuniter demokrasi digambarkan sebagai "a mode of associated living, of conjoint communicated experience." ${ }^{64}$ Ada dua tanda yang dapat dijadikan alat untuk mendeteksi apakah demokrasi benar-benar nyata di dalam hidup bersama. ${ }^{65}$ Pertama, adanya kesediaan dan komitmen setiap individu untuk berbagi hidup dan terlibat di dalam membangun hidup bersama yang menghargai kebebasan,

57 John Dewey, "The Need of an Industrial Education in an Industrial Democracy," in The Political Writings, p. 121.

58 John Dewey, “The Need of an Industrial Education in an Industrial Democracy," p. 121.

59 "A state of social life where there is a wide and varied distribution of opportunities; where there is social nobility or scope for change of position and station; where there is free circulation of experiences and ideas, making for a wide recognition of common interests and purposes, and where utility of their warm and constant support in its behalf." John Dewey, "The Need of an Industrial Education in an Industrial Democracy," p. 122.

60 John Dewey, “The Need of an Industrial Education in an Industrial Democracy," p. 124. 
kesetaraan, dan persaudaraan. Kedua, adanya relasi antar-kelompok masyarakat yang memerdekakan, menciptakan habitus sosial (kebiasaan hidup bersama yang baik), dan bertanggung jawab terhadap masa depan hidup manusia. Dengan demikian, sekali lagi Dewey mene-gaskan bahwa demokrasi merupakan proses pendidikan masyarakat sipil yang peduli dan bertanggung jawab terhadap masa depan umat manusia.

Penegasan tentang aspek komuniter demokrasi menjadi penting di tengah situasi masyarakat yang cenderung memahami kebebasan secara individual dan melepaskannya dari tanggung jawab sosial. Dewey mengingatkan bahwa demokrasi tidak boleh tercabut dari aspek alamiah manusia sebagai makhluk sosial. Ia menegaskan bahwa demokrasi "can be exhibited and become forceful or actual only in relationship with other." 66 Kebebasan di dalam demokrasi semestinya dihayati dalam relasi timbal balik antarpribadi dan kelompok di dalam upaya mengembangkan hidup menjadi lebih bermakna. ${ }^{67}$ Relasi antarpribadi dan kelompok merupakan medan penghayatan nilai-nilai demokrasi secara dinamik sehingga bertumbuhlah pemahaman dan kesadaran untuk saling membantu dalam memperjuangkan kebaikan bersama.

Demokrasi berakar kokoh dan menjadi nyata di dalam kehidupan bersama yang menjunjung tinggi kebebasan, kesederajatan, dan persaudaraan yang akan membuahkan hidup damai. Keyakinan ini ditegaskan Dewey dengan jelas dalam pernyataan berikut:

Sebuah komunitas terbentuk manakala terjadi aktivitas bersama yang konsekuensinya diapresiasi sebagai hal yang baik bagi semua pribadi yang ambil bagian dalam aktivitas itu. Aktivitas bersama tersebut merupakan tempat diwujudkannya hal yang baik itu sedemikian sehingga mempengaruhi keinginan dan upaya enerjetik untuk mempertahankan kegiatan tersebut sebagai hal yang adil karena hal itu diterima oleh semua. ${ }^{68}$

61 John Dewey, Freedom and Culture, p. 119.

62 John Dewey, "Creative Democracy," p. 242.

63 John Dewey, Freedom and Culture, p. 143.

64 John Dewey, Democracy and Education, p. 87.

65 John Dewey, Democracy and Education, p 86.

66 John Dewey, "Philosophy and Democracy," p. 46. 
Ungkapan tersebut menjelaskan bahwa kesadaran akan tanggung jawab membangun hidup bersama yang semakin manusiawi (hidup berkomunitas) merupakan aspek penting dari demokrasi. ${ }^{69}$ Dengan menegaskan aspek etis dan komuniter demokrasi, ada dua hal pokok yang mau dinyatakan oleh Dewey. Pertama, ia memperjuangkan agar nilainilai demokrasi menjiwai seluruh aspek kehidupan manusia di dalam masyarakat dan bukan hanya menjadi ide abstrak yang tanpa isi. ${ }^{70}$ Kedua, perjuangan untuk menghayati nilai-nilai demokrasi dalam hidup bersama merupakan proses yang melibatkan seluruh aspek hidup manusia. Untuk itu ia menegaskan bahwa "communal life is moral, that is emotionally, intellectually, consciously sustained."71

Di tengah keprihatinan akan adanya gejala reduksi demokrasi, Dewey mengingatkan kembali makna dari pilar-pilar penting demokrasi. Ia menegaskan:

Persaudaraan adalah nama lain bagi nilai-nilai yang dihargai secara sadar yang bertumbuh dari sebuah perserikatan tempat semua anggota berbagi, dan yang memberikan arah kepada perilaku masing-masing anggota. Kebebasan adalah perwujudan dan peme-nuhan yang aman dari potensi-potensi pribadi yang terjadi hanya di dalam perserikatan yang kaya dan beragam dengan orang-orang lain: kekuatan untuk menjadi diri sendiri yang unik sebagai sum-bangan yang khas, dan kekuatan untuk menikmati buah-buah per-serikatan dalam caranya sendiri. Kesederajatan memungkinkan setiap anggota perserikatan memberikan sumbangan yang tak ter-batas sebagai konsekuensi dari tindakan bersama. Hal itu sederajat karena diukur hanya dengan kebutuhan dan kemampuan untuk menggunakannya, dan bukan dengan faktor-faktor dari luar yang dipaksakan supaya orang lain dapat mengambilnya atau memi-likinya. ${ }^{72}$

Untuk memberi pendasaran hidup bersama di dalam masyarakat industri, Dewey menegaskan:

67 John Dewey, "Philosophy and Democracy," p. 47.

68 "Whenever there is conjoint activity whose consequences are appreciated as good by all singular persons who take part in it, and where the realization of the good is such as to effect an energetic desire and effort to sustain it in being just because it is a good shared by all, there is in so far a community." John Dewey, The Public and Its Problems, p. 149.

69 John Dewey, Democracy and Education, p. 149.

70 John Dewey, Democracy and Education, p. 149.

71 John Dewey, Democracy and Education, p. 151. 
Ketika saya berpikir mengenai kondisi-kondisi di mana baik laki-laki maupun perempuan hidup di berbagai negara asing saat ini, tentang ketakutan untuk dimata-matai dengan bahaya yang membayangi pertemuan antarteman guna mengadakan percakapan yang penuh persahabatan dalam perkumpulan privat, saya cenderung untuk mempercayai bahwa inti dan jaminan akhir dari demokrasi terdapat dalam perkumpulan-perkumpulan bebas yang dilakukan oleh orang-orang yang hidup saling berdekatan di pojok-pojok jalan untuk mendiskusikan apa yang mereka baca dalam berita-berita hari itu yang tidak disensor, dan dalam perkumpulan antarteman yang mereka adakan di ruang tamu dalam rumah atau apartemen mereka untuk berbicara kepada satu sama lain secara bebas. ${ }^{73}$

Kutipan di atas menegaskan pentingnya pengembangan komuni-tas yang ditandai dengan relasi alamiah di dalam hidup bersama, kese-diaan untuk berbagi pengalaman hidup, dan komunikasi dalam sema-ngat kerja sama. $^{74}$

Penjelasan tentang aspek etis dan komuniter demokrasi menegaskan bahwa demokrasi sesungguhnya berhubungan dengan cara dan gaya hidup yang didasari oleh nilai-nilai manusiawi (kebebasan, kesede-rajatan, dan persaudaraan). Dengan demikian, upaya untuk mengem-bangkan demokrasi harus bersentuhan dengan pengembangan kecer-dasan dan tanggung jawab sosial bagi setiap pribadi sebagai warga masyarakat. Dengan pertimbangan itu, kepedulian Dewey adalah budaya demokrasi atau cara hidup berkomunitas berdasarkan nilai-nilai demo-krasi. ${ }^{75}$

\section{BUDAYA DEMOKRASI}

72 "Fraternity is another name for consciously appreciated goods which accrue from an association in which all share, and which give direction to the conduct of each. Liberty is that secure release and fulfilment of personal potentialities which take place only in rich and manifold association with others: the power to be an individualized self making a distinctive contribution and enjoying in its own way the fruits of association. Equality donates unhampered share which each individual member of the community has in consequences of associated action. It is equitable because it is measured only by need and capacity to utilize, not by extraneous factors which deprive on in order that another may take and have." John Dewey, Democracy and Education, p. 150.

73 "When I think of the conditions under which men and women are living in many foreign countries today, fear of espionage, with danger hanging over the meeting of friends for friendly conversation in private gathering, I am inclined to believe that the heart and final guarantee of democracy is in free gatherings of neighbors on the street corner to discuss back and forth what is read in uncensored news of the day, and in gatherings of friends in the living room of 
Dewey melihat bahwa persoalan kemanusiaan pada zamannya tidak dapat disempitkan sebagai persoalan politik. Ia menegaskan:

Sekarang kita mengetahui bahwa relasi-relasi yang terjadi antara pribadi-pribadi di luar institusi-institusi politik - relasi-relasi industri, relasi-relasi komunikasi, relasi-relasi ilmu pengetahuan, dan relasi-relasi kesenian dan agama-mempengaruhi perserikatan-perserikatan dalam keseharian, oleh karenanya juga mempe-ngaruhi secara mendalam sikap-sikap dan kebiasaankebiasaan yang diungkapkan dalam pemerintahan maupun hukum. Bila benar bahwa reaksi politis dan legal membentuk hal-hal yang lain, akan lebih benar lagi bahwa institusi-institusi politik merupakan efek dan bukan penyebab. ${ }^{76}$

Melalui pernyataan di atas, Dewey menunjukkan betapa kompleks kenyataan hidup manusia. Dari situ, ia menegaskan bahwa persoalan politik hanyalah bagian dan efek dari kenyataan hidup manusia. Mengingat demokrasi merupakan seperangkat nilai manusiawi yang semes-tinya menjiwai seluruh aspek hidup manusia, jelaslah tidak memadai melihat demokrasi hanya dari aspek politik.

Dewey melihat bahwa segala kompleksitas hidup manusia itu tiada lain adalah budaya. ${ }^{77}$ Dalam konteks masyarakat industri, dinamika budaya sangat dipengaruhi dan ditentukan oleh faktor ekonomi. Dengan tegas Dewey menyatakan "that economic factors are an intrinsic part of culture that determines the actual turn taken by political measures and rules."78 Adanya mesin-mesin industri semakin memperluas pengembangan industri, melipatgandakan modal dan memberi pengaruh sangat kuat terhadap pola hidup masyarakat (budaya). John Dewey menegaskan: "our law and politics and the incidents of human association depend upon a novel combination

houses and apartments to converse freely with one another." John Dewey, Creative Democracy...., p. 243.

74 James Campbell, “Dewey's Conception of Community," in Reading Dewey: Interpretation for a Postmodern Generation, edited by Larry A. Hickman (Indianapolis: Indiana University Press, 1998), pp. 33-34.

75 John Dewey, Democracy and Education, p. 147.

76 "For we now know that the relations which exist between persons, outside of political institutions, relations of industry, of communication, of science, art and religion, affect daily associations, and thereby deeply affect the attitudes and habits expressed in government and rule of law. If it is true that the political and legal react to shape the other things, it is even true that political institutions are an effect, not a cause." John Dewey, Freedom and Culture, p. 13. 
of the machine and money, and the result is the pecuniary culture characteristic of our civilization." ${ }^{79}$ Dengan kata lain, perkembangan industri memberi pengaruh sangat luas terhadap terbentuknya budaya baru, yang dapat dinamakan sebagai budaya industri.

Dewey memberi catatan kritis terhadap perkembangan budaya yang sangat dipengaruhi oleh perkembangan industri. Secara jelas ia menegaskan:

Faktor-faktor lain yang sangat kuat dalam interaksi adalah teknologi yang dihasilkan oleh ilmu pengetahuan modern yang telah melipatgandakan sarana-sarana untuk memodifikasi disposisi massa dalam masyarakat; dan yang - dalam kaitan dengan sentralisasi ekonomi - telah memampukan pendapat massa menjadi produksi massal seperti benda-benda fisik. Dalam peristiwa seperti ini sekaligus merupakan sebuah peringatan maupun usulan bagi mereka yang memiliki kepedulian terhadap situasi budaya yang mempertahankan kebebasan demokratis. Peringatannya jelas: hal itu berperan sebagai propaganda yang sekarang berlangsung dalam diri kita dalam saluran-saluran yang tidak terlalu langsung dan kurang resmi. Usulannya adalah bahwa media cetak dan radio yang telah membuat penggunaan secara cerdik dan jujur sarana-sarana komunikasi untuk menyatakan tujuan umum secara terbuka, merupakan hal yang fundamental. ${ }^{80}$

Dari kutipan di atas, kita dapat melihat pengamatan Dewey bahwa perkembangan industri tidak dapat dipisahkan dari peran media massa. Adalah penting mengembangkan sikap kritis terhadap media di era industrialisasi. Sering kali di balik berbagai tayangan media termuat kepentingan-kepentingan terselubung yang menguntungkan kelompok tertentu. ${ }^{81}$ Film, sinetron, dan iklan berhubungan erat dengan kepentingan industri yang diam-diam membangun pola pikir pragmatis dan pola hidup yang cenderung konsumtif. Akibatnya, pola pikir kritis dan kreatif mulai terkikis dari kehidupan masyarakat yang dengan bangga mengatakan sebagai masyarakat demokratis (paling tidak secara politik berideologi demokrasi).

Supaya demokrasi tetap relevan dan memberi pengaruh terhadap pengembangan budaya, Dewey menegaskan kembali pentingnya melihat

77 John Dewey, Freedom and Culture, p. 15.

78 John Dewey, Freedom and Culture, p. 15.

79 John Dewey, Individualism: Old and New, p. 9. 
aspek moral demokrasi. Ia menyatakan bahwa "the moral factor is an intrinsic of the complex of social forces called culture." ${ }^{82}$ Dengan melihat demokrasi dari perspektif moral, Dewey mencermati bahwa ancaman terhadap demokrasi bukan hanya perkembangan ideologi yang bertendensi totalitarian ${ }^{83}$ melainkan juga berasal dari sikap dan perilaku pribadipribadi dan kelompok-kelompok yang ada di tengah masyarakat. ${ }^{84}$ Mengembangkan demokrasi tidak cukup hanya dengan cara memerangi berbagai ideologi yang anti demokrasi. Mengembangkan demokrasi berarti mentransformasikan sikap dan perilaku berdasarkan nilai-nilai demokrasi. Untuk itu, Dewey menegaskan:

Tugas dari mereka yang memegang kepercayaan akan demokrasi adalah menghidupkan dan mempertahankan dengan segala kekuatan keyakinan asli dari sifat dasar moral demokrasi, yang diungkapkan dengan cara-cara yang sesuai dengan kondisi budaya sekarang. Kita telah maju begitu jauh untuk mengatakan bahwa demokrasi adalah sebuah pola hidup. Kita masih perlu mewujudkannya sebagai pola hidup pribadi dan yang menyediakan standar moral bagi tingkah laku pribadi. ${ }^{85}$

Apa yang dimaksud dengan budaya demokrasi? Budaya demokrasi merupakan cita-cita yang harus diperjuangkan secara nyata; artinya, demokrasi tercermin di dalam pemikiran dan tindakan (way of life) setiap individu di dalam relasi dengan sesama. ${ }^{86}$ Nilai-nilai demokrasi menjiwai sikap dan perilaku yang mendasari relasi antarindividu di dalam hidup bermasyarakat. Untuk itu, Dewey menegaskan bahwa demokrasi merupakan "a moral standard for personal conduct." 87

Gagasan dan cita-cita tentang demokrasi sebagai sebuah pola hidup

80 "Other powerful factors in interaction are those technologies produced by modern science which have multiplied the means of modifying the dispositions of the mass of the population; and which, in conjunction with economic centralization, have enabled mass opinion to become like physical goods a matter of mass production. Here also is both a warning and a suggestion to those concerned with cultural conditions which maintain democratic freedom. The warning is obvious as to the role of propaganda, which now operates with us in channels less direct and less official. The suggestion is that the printing press and radio have made the problem of intelligent and honest use of means of communication in behalf of openly declared public ends a matter of fundamental." John Dewey, Individualism: Old and New, p. 36.

81 John Dewey, Individualism: Old and New, p. 38.

82 John Dewey, Individualism: Old and New, p. 17.

83 John Dewey, Individualism: Old and New, p. 44.

84 John Dewey, Individualism: Old and New, p. 44. 
didasarkan pada beberapa argumentasi Dewey. Pertama, "democracy is a way of life controlled by a working faith in the possibilities of human nature." 88 Melalui pernyataan itu, Dewey menyampaikan keyakinannya bahwa setiap individu memiliki hak dan kesempatan untuk mengembangkan diri dan mewujudkan segala potensi dirinya di dalam hidup bersama. ${ }^{89}$ Kedua, "democracy is a way of life controlled not merely by faith in human nature in general but by faith in the capacity of human beings for intelligent and judgment and action if proper conditions are furnished." ${ }^{90}$ Selain meyakini bahwa setiap individu memiliki potensi alamiah, Dewey juga menun-jukkan kekhasan manusia yang memiliki kecerdasan dan kemampuan bertindak yang didukung oleh situasi yang kondusif. Setiap individu memiliki tanggung jawab untuk mengembangkan dan menggunakan potensi-potensi dirinya untuk mengembangkan hidup bersama berdasarkan nilai-nilai demokrasi. Masyarakat atau komunitas sebagai kebersamaan yang dibangun oleh individu-individu berperan sebagai ruang yang kondusif bagi individuindividu untuk mewujudkan potensi-potensi dirinya selaras dengan citacita kebaikan hidup bersama. ${ }^{91}$ Hidup yang cerdas baik secara individual maupun sosial (pemikiran, sikap, dan tindakan) merupakan tolok ukur demokrasi sebagai sebuah pola hidup.

Beberapa gagasan di atas menunjukkan bahwa yang dimaksud dengan budaya demokrasi adalah proses kehidupan bersama yang ditandai oleh kebebasan dan tanggung jawab setiap individu untuk membangun hidup bersama berdasarkan nilai-nilai demokrasi. Budaya demokrasi berkembang

85 "The task of those who retain belief in democracy is to revive and maintain in full vigor the original conviction of intrinsic moral nature of democracy, now stated in ways congruous with present conditions of culture. We have advanced far enough to say that democracy is a way of life. We have yet to realize that it is a way of personal life and one which provides a moral standard for personal conduct." John Dewey, Freedom and Culture, p. 101.

86 "We realize in thought and act that democracy is a personal way of individual life; that it signifies the possession and continual use of certain attitudes, forming personal character and determining desire and purpose in all the relation of life." John Dewey, "Creative Demo-cracy....," p. 241.

87 John Dewey, Freedom and Culture, p. 101.

88 John Dewey, “Creative Democracy....," p. 242.

89 John Dewey, “The Basic Values....," p. 208. 
di dalam kehidupan komunitas-komunitas. Tentang karakter komunitas, ia menambahkan:

Sebuah komunitas terbentuk manakala terjadi aktivitas bersama yang konsekuensinya diapresiasi sebagai hal yang baik bagi semua pribadi yang ambil bagian dalam aktivitas itu. Aktivitas bersama tersebut merupakan tempat diwujudkannya hal yang baik itu sedemikian sehingga mempengaruhi keinginan dan upaya enerjetik untuk mempertahankan kegiatan tersebut sebagai hal yang adil karena hal itu diterima oleh semua. ${ }^{22}$

Perjuangan untuk mengembangkan demokrasi sebagai sebuah pola hidup merupakan tugas dan tanggung jawab setiap individu di dalam kehidupan sehari-hari di tengah masyarakat. Demokrasi merupakan proses hidup yang berlangsung secara kontinyu. Gagasan ini tampak dalam pernyataan Dewey: "Since it is one that have no end till experience itself comes to an end, the task of democracy is forever that of creation of freer and more human experience in which all share and to which all contribute. "93 Dua pilar penting dari budaya demokrasi adalah nilai-nilai (kebebasan, kesederajatan, dan persaudaraan) dan transformasi hidup setiap indi-vidu agar semakin mampu menghayati nilai-nilai tersebut di dalam hidup berkomunitas secara terus-menerus. Dengan menekankan dua pilar demokrasi tersebut, Dewey ingin menegaskan bahwa demokrasi meru-pakan kenyataan yang dinamis, tercermin dalam seluruh aspek hidup manusia dan membuahkan kehidupan bersama yang cerdas dan damai. Ukuran tertinggi dari demokrasi adalah berkembangnya kehidupan bersama yang cerdas dan damai sehingga setiap individu terlibat untuk memberikan sumbangannya yang khas bagi perkembangan sesama dan masyarakat. ${ }^{94}$

\section{PENUTUP}

John Dewey menegaskan bahwa demokrasi mempunyai makna yang lebih mendalam daripada persoalan politik. Demokrasi merupakan

90 John Dewey, "Creative Democracy....," p. 241.

91 John Dewey, The Public and Its Problems, p. 147.

92 "Whenever there is conjoint activity whose consequences are appreciated as good by all singular persons who take part in it, and where the realization of the good is such as to effect an energetic desire and effort to sustain it in being just because it is a good shared by all, there is in so far a community." John Dewey, The Public and Its Problems, p 149. 
gagasan etis yang mendasari hidup bersama (berkomunitas). Kebebasan, kesederajatan, dan persaudaran berhubungan dengan cita-cita hidup bersama yang didasarkan pada suatu keyakinan bahwa setiap individu merupakan subjek yang bebas untuk mewujudkan segala potensi dirinya.

Pemerintahan yang demokratis hanya mungkin dibangun ketika masing-masing individu dan kelompok masyarakat terlibat dan bertanggung jawab di dalam mengembangkan hidup bersama berdasarkan nilainilai demokrasi. Demokrasi merupakan proses budaya atau dinamika hidup bersama yang dijiwai oleh nilai-nilai kebebasan, kesederajatan, dan persaudaraan. Dengan demikian, demokrasi sebagai nilai-nilai ideal hadir secara nyata di dalam kehidupan setiap individu dan kelompok masyarakat yang saling mencerahi (mentransformasikan), bertanggung jawab sosial, dan damai. Itulah yang Dewey maksud sebagai budaya demokrasi atau demokrasi sebagai pola hidup.

Pemikiran Dewey tentang budaya demokrasi layak dicuatkan di tengah situasi masyarakat yang masih diwarnai cara-cara dan perilaku kekerasan baik lokal maupun global. Kekerasan dan perang merupakan sikap dan tindakan anti demokrasi. Dewey juga mengingatkan bahwa perilaku media yang cenderung mempublikasikan dan menayangkan kekerasan dan berbagai tayangan sensasional membawa akibat buruk bagi demokrasi karena hal itu akan membangun pola pikir dan perilaku yang menganggap kekerasan sebagai hal yang biasa. ${ }^{95}$

Gagasan Dewey mengenai demokrasi sebagai proses pendidikan atau transformasi budaya dengan menekankan hak dan tanggung jawab setiap individu untuk saling mengembangkan kemampuannya secara maksimal wajib dipertimbangkan agar demokrasi tidak sekedar dimengerti secara politis. Adalah penting memahami dan memaknai demokrasi sebagai proses dialog interaktif untuk menghayati nilai-nilai kebebasan, kesede-rajatan, dan persaudaraan dalam upaya mengembangkan hidup damai di tengah masyarakat global dan keanekaragaman budaya. ${ }^{96}$ Dewey berupaya agar

93 John Dewey, "Creative Democracy....," p. 245.

94 John Dewey, Reconstruction in Philosophy, p.186. 
keterbukaan untuk selalu berdialog dan belajar semakin tumbuh dalam masyarakat agar nilai-nilai demokrasi secara nyata dapat dihayati di dalam dinamika kehidupan sehari-hari.

\section{DAFTAR RUJUKAN}

Bullet, Garry. The Politics of John Dewey. New York: Buffalo Press, 1983.

Campbell, James. Understanding John Dewey: Nature and Cooperative Intelligence. Chicago: Open Court, 1995.

Dewey, John. Democracy and Education: An Introduction to the Philosophy of Education. New York: The Free Press, 1966.

95 KOMPAS, 16 Agustus 2009, mencatat bahwa peristiwa penggerebekan beberapa orang yang dikenal sebagai anggota jaringan terorisme yang terjadi di Temanggang pada 7-8 Agustus 2009 merupakan salah satu contoh bahwa media memproduksi kekerasan imaginer. Peristiwa itu telah menyita perhatian 44 persen pemirsa televisi di Indonesia.

96 CB. Mulyatno, "Pendidikan yang Bervisi Sosial: Kajian Kritis atas Pemikiran John Dewey," Widya Dharma 15 (2004): 38. 
. "The Democratic Faith and Education." In Jo Ann Boydston, ed., The Later Works XV. Carbondale: Southern Illinois University Press, 1989, pp. 250-260.

. The Early Works 1882-1898: Early Essays and Study of EthicsA Syllabus 1882-1894. Volume IV. Carbondale: Southern Illinois University Press, 1971.

. Experience and Education. New York: MacMillan Publishing Company, 1963.

. Freedom and Culture. New York: G.P. Putnam's Sons, 1989.

. Individualism: Old and New. New York: Minton, 1999.

2000.

Liberalism and Social Action. New York: G.P. Putnam's Sons,

The Public and Its Problems. New York: Henry Holt, 1997.

Reconstruction in Philosophy. Boston: Beacon Press, 1948.

Haryatmoko. Etika Komunikasi: Manipulasi Media, Kekerasan dan Pornografi. Yogyakarta: Kanisius, 2007.

Hickman, Larry A., ed. Reading Dewey: Interpretation for a Postmodern Generation. Indianapolis: Indiana University Press, 1988.

Morris, Debra and Ian Shapiro, eds. The Political Writings. Indianapolis: Hackett Publishing Company, 1993.

Mulyatno, CB. "Pendidikan yang Bervisi Sosial: Kajian Kritis atas Pemikiran John Dewey." Widya Dharma 15 (2004): 31-42.

"Philosophy as An Educative Prosess in John Dewey (sic) Pragmatism." Studia Philosophica et Theologica 9 (2009): 67-84.

Rockefeller, Stefen C. John Dewey: Religious Faith and Democratic Humanism. New York: Columbia University Press, 1991.

Schiller, Friedrich. On the Aesthetic Education of Man. Mineola, NY: Dover Publications, Inc., 2004.

Schilpp, Paul Arthur, ed. The Philosophy of John Dewey. Volume I. New York: The Library of Living Philosophers, 1951.

Sills, David, ed. International Encyclopedia of the Social Science. Volume V. New York: The MacMillan Company \& Then Free Press, 1968.

Tindall, George Brown and David Emory Shi. America: A Narrative History. New York: Norton \& Company, 2000.

Westbrook, Robert W. John Dewey and American Democracy. Ithaca: Cornell University Press, 1991. 